\title{
Career and Family Strategies of Executive Women:
}

\section{Revisiting the Quest to "Have It All"}

\author{
SOUHA R. EZZEDEEN
}

I guess there is one thing I would add, and that is the lack of role models in the press of women who are high-powered executives, are married, and who have younger kids. I just don't feel that story is told. Everyone I have ever asked who is working who has a couple of kids I say, "How do you make it work?" and they say, "You just do." And I accept that as an answer because I know "just do" is different for everybody, but I actually would like to know more specifically what that means.

-Executive woman, study participant

\section{INTRODUCTION}

With more women attaining leadership positions in organizations, there has been much debate in recent years about whether executive women can "have it all," meaning a high-powered career and a family. We believe that this debate, whether in academic circles or in the public discourse, has been dominated by perspectives of conflict and choice, whereby career ambitions and close family relationships are viewed as irreconcilable for women. One particularly loud message in the popular press has been the "opting out" of professional women who are presumably answering the call of motherhood and choosing childbearing over career. Putting aside the real reasons behind these trends, if they are trends at all, the prevailing message remains that a choice must be made.

We are not denying that aspiring women should be aware of the glass ceiling, nor do we underestimate the general lack of organizational, societal, and institutional support they experience in trying to combine career and family. However, studies show that succeeding at a single endeavor seldom amounts to feelings of genuine success and fulfillment. Engaging in multiple domains of life such as work, family, and community is healthier for people. Working outside

\author{
KRISTEN G. RITCHEY
}

the home is especially good for women as it boosts their self-esteem and enhances their parenting. Thus, we believe that the question of how some women manage to balance executive careers with family is a more positive inquiry than the one exploring why they sometimes cannot. Understanding the twists and turns of Brenda Barnes's career from PepsiCo Inc. to Sara Lee and the ways in which Karen Hughes managed to retain an influential role in the Bush White House after returning to Texas are more helpful and empowering stories than tales about why these women once chose family over high-profile jobs.

Here, we address young and ambitious women who are reflecting upon their career and family goals within a gender environment that is at once in flux and holding on steadfastly to certain norms. Our goal is to change the course of the debate on becoming an executive woman and having a family life by presenting case studies derived from a study of 25 executive women in family relationships. These examples show that the importance of particular roles varies over time, and adjustments can be made that allow women to be fulfilled in both their work and personal lives. Our study offers a measure of hope that choices between career and family can be avoided. The cases we present also suggest that the expressions "worklife balance" and "having it all" remain problematic in many respects.

\section{ON BEING AN EXECUTIVE AND HAVING A LIFE}

Although the recent economic downturn has reinvigorated debates on executive pay and accountability, organizational leaders remain among the most highly regarded and influential members of society. Their positions are hard to reach, require considerable skill and dedication, and are granted sizeable prestige, power, and financial rewards. But the pace of executive work exerts great physical and mental demands on 
men and women alike. Senior executives are ultimately accountable for their organizations, and their lives become deeply embedded therein. Managerial work has also become more complex with global competition and an increasingly stringent institutional environment. Finally, the inordinate demands of executive work impose great stress on the personal lives of executives, often harming their relationships, sense of balance, and happiness.

\section{Men and Women: Different Roads to Rome?}

Extensive evidence indicates that men and women follow different paths to senior management; ambitious men can dedicate themselves to work while women experience barriers to advancement stemming from social exclusion, tokenism, and lack of executive development opportunities. These combine to create what is known as the "glass ceiling." The recent historic appointment of one woman to succeed another at Xerox Corp. does not diminish the reality that as recently as 2000 , almost 50 percent of firms in the Fortune 1000 had no women among senior management, and perhaps only 6 percent of CEOs in these firms will be women by 2016 if current trends continue (see the 2006 study of Helfat, Harris, and Wolfson in Academy of Management Perspectives). Arguments that there are not many eligible women in the pipeline, that women lack ambition, or would rather be mothers have been largely discredited. Rather, the stereotype of women as caring and communal clashes with the characterization of leaders as strong and independent, impeding women's progress.

\section{Can Ambitious Women Have it All?}

In terms of combining an executive career with a family, social norms and workplace cultures converge to create very different pictures for men and women. For women, the executive career/family combination is problematic, because women generally do not have access to full-time help from husbands comparable to what stay-at-home wives provide to men. The distinction between caregiver and breadwinner tends to further solidify when couples have children. The fact that women still assume primary responsibility for domestic work can undermine their ability to devote themselves to the requirements of career advancement. Single executive women, on the other hand, are said to have a hard time finding eligible mates, given that accomplished men are not always interested in an equally accomplished partner. Indeed, evidence suggests that the more "vulnerable" a woman is perceived, the more attractive she is perceived to be, so career success for women can bode defeat in the marriage realm. In addition, women's need to perform in male-dominated corporate environments can reduce their time available to nurture relationships and shorten their biological window to have children.

\section{OUR RESEARCH}

Two competing arguments exist regarding the nature of work-nonwork interactions. The dominant paradigm has been the inherent conflict between work and everything else, given the finite nature of time and energy. Rivaling this idea is the notion that individuals also gain tremendous fulfillment from participating in multiple domains. Work-family facilitation or enrichment consists of individuals experiencing enhanced wellbeing from multiple role participation due to the positive transfer of resources and feelings between domains.

However, the reality that women's career ambition and family life can and often do clash has been the main focus of research, and we believe not enough attention has been granted to how women can combine managerial work with a fulfilling family life. We fear that this biased focus can lead women to believe that they must indeed choose between career and family. In doing so, however, they miss the opportunity to lead a rich, multifaceted existence. Organizations across the board also lose women's capacity to deal with the managerial problems of the day, said to be tackled particularly well by women.

Thus, we wanted to study how some women managed to become executives and enjoy family. We were especially interested in the stance of their intimate partner, given the nontraditional nature of their relationship. Through referral, we targeted women in leadership positions who were in an intimate partnership, whether or not it involved an official marriage or children. We interviewed 25 women who held titles such as CEO (chief executive officer), president, and vice president at public and private companies, government agencies, and nonprofits, spanning a wide range of industries. Our interviews addressed these women's career progression, challenges encountered along the way, and coping strategies. We present here the experiences of seven women who experienced career advancement and family life very differently. They molded their professional and personal lives to achieve a balance that reflected their values and accounted for their circumstances (Note that names have been changed to preserve these women's anonymity).

\section{Elizabeth Craig: The Busy Entrepreneur}

Elizabeth Craig is the 34-year-old founder and director of a private consulting firm - with a part-time faculty job and a busy family life with a young son. She 
loves what she does, but experiences considerable stress trying to exceed her clients' expectations, managing a virtually connected workforce, and coping with the loneliness at the top of her company. She strives to make time for things other than work and takes Fridays off to run errands and to get together with her women friends, gatherings they have come to call "detox Fridays."

The early days of her career saw her heading the for-profit arm of a national advocacy group, running entrepreneurial projects to generate revenue. For many years, Liz was status-driven, often asking, "How high can I get? What's on the business card?" But she soon realized that the politics and grueling work hours of the corporate route were just not for her. After much job and soul searching, she eventually mustered the courage to start her own firm, a now thriving consultancy that recently launched a research division.

Liz credits several factors for her success, notably a unique capacity to take measured risks and not being afraid of "jumping off the cliff." She mentions the importance of her Ivy League education, which she says gave her "paper credentials." She also believes she would not be where she is without the support of Nate, her husband of seven years. A seasoned entrepreneur, Nate encouraged Liz to apply to graduate school and to start her business. He provided her with technical assistance and a great deal of support in the process. She describes Nate as her "best friend" and a good father.

However, Liz always strives to arrange her life around his. She is not sure that he would be as "skilled" at doing the same for her. She believes that women are generally better at asking: "What's the context here? And how can I make it the best for everybody, myself included, given this context?" Nate's help around the house also leaves much to be desired. She admits that she just could not do without her nanny, whom they can afford thanks to their combined income. Liz recognizes that Nate can get "a little bit old school" and feels that a compromise around their roles needs to be reached somehow.

\section{Mary Sebastian: Powerful Equals}

Mary Sebastian is a 55-year-old university president, a role that involves long workdays and a great deal of travel. She believes the most stressful aspect of her work is reconciling the "competing devotions" between work and family, which she still struggles with although her children are now adults. But she adds that this "just forces you to be more organized and set your priorities straight."

Mary's career trajectory was fairly traditional for an academic administrator. She started as a professor and established strong research credentials before moving into administration. She credits her hard work, mentors, and opportunities along the way to reach her position. But she also felt at times like a lone warrior. "No one ever said to me, 'We're going to take you to the next level,"' she says.

Another contributor to her success has been her willingness to surround herself with honest individuals, as opposed to "people who will tell you everything is fine." She indicated that the importance of social support actually grows as one advances through the ranks, because it becomes even more important to hear different perspectives. Her co-workers, former students, and past professors provide these valuable perspectives, as does Steve, her husband of over 30 years.

Steve started his career as a professor and later also became a senior administrator. His support was crucial to Mary's development since their early days together as students. She says they often took turns tending to their home, looking after their children, and meeting their work responsibilities. But because he was ahead of her on the career ladder, she followed him where his career led, and had to somehow "start over" each time, which "was not always a happy thing." Even so, she credits Steve for helping around the house and with the children because they often moved far from friends and family. Eventually their income allowed them to pay for help.

Over the years, they were of great professional assistance to each other, reviewing each other's work and advising each other's decisions. Today, they attend functions together and "schmooze each other's donors." Mary says: "I think it was a great thing for us to understand each other's environment, just having knowledge of what the day-to-day life is like. I mean, you just know the territory." Her love for Steve is evident in how she describes him as "enlightened" and having an "intact ego," a man whose support was not just professional but emotional as well. While assertive in her leadership role, she admits to "fretting" over family matters:

When it comes to my children and my mother, I overreact, I fret, I ruminate, and I depend on him for being very straight and sort of putting me back together. But we are equals when it comes to the professional world.

\section{Helen Williams: Sinuous Paths at Home and Work}

One would be hard-pressed to make sense of 41year-old Helen Williams' résumé. She held jobs as disc jockey, financial analyst, operations manager, and consultant. She is now the managing director of a large consulting firm and describes herself as a "road warrior" given her extensive travel. She says: "I've always 
done what I love and I love what I do, so that's been the driving force. I've never restricted myself, my mindset, that I can only do one thing, or be one thing." She credits her "exceedingly accomplished" parents, in particular her mother, who always worked while keeping a "perfect" home. Helen also believes that making it to the top requires self-confidence and tenacity. She mentions feeling lucky to have had competent and supportive bosses along the way.

On the home front, however, it took two failed marriages before Helen found a suitable partner. She describes her first two marriages as "business arrangements," where the unfettered pursuit of advancement and material success was the focus. Things are different with fiancé Jeffrey, whose interest is the couple's health rather their individual accomplishments. Jeff is supportive of Helen's career, but also believes that work and family boundaries are important to their health and wellbeing. He has been clear with Helen that the "road warrior stuff" should not become habit because "you can work yourself into an early grave if you just never stop." Jeff also regulates Helen's "reactionary" temperament, which she says "rescued" her more than once. She says Jeff is the "the first person that I've ever been with that I could actually go toe-totoe with" and she credits their similar backgrounds and comparable achievements as strengthening their relationship.

\section{Beatrice Bilyk: Allowed to Fly}

Paul and Beatrice Bilyk were in junior high when they first met. He took her to her first prom, and they dated for some time until Beatrice went off to college and Paul joined the military. They later reunited and were married. He ran his business, and she started a career in government. By the time she retired 30 years later, Beatrice had reached the highest nonpolitical position of her agency, a large and notoriously maledominated organization.

Though she "loved every minute of it," her work was unpredictable, stressful, and busy, and her rise to the top was rocky. She started as a trainee and talked to us emphatically about her first boss, an army veteran who treated his subordinates with extraordinary respect, aiming to have them "know more than he did." The bosses who followed were not nearly as supportive, Beatrice explained, which she attributed to the technology-oriented and male-dominated culture of her organization ("It is really, really a man's world").

Beatrice worked for several years as a supply chain analyst, becoming intimately familiar with the organization's inner workings. Still, she was passed over for promotions several times because men with technical credentials were chosen instead. She witnessed these appointments fail before she was finally given a shot at leadership. She says: "I was never bitter about it. I always figured out it would work out in the end." Her performance earned her respect from her colleagues, especially following a crisis in the department that tested her mettle. After that, she says, she was "allowed to fly."

But Beatrice is adamant that she could not have had such a career without Paul's support. She says many factors cemented their marriage - including being from the same area, having common values, and Paul's general respect for women. It was several years before they had children, but when they did, Paul decided that he would run his business from home to take care of their children full-time, as neither wanted babysitters. Despite how unusual this arrangement was back in the seventies, Paul's decision was "the most natural thing." The years went by as Beatrice worked her way to the top, with long hours and frequent travel. She says Paul allowed her to never have to say to her boss that she "couldn't do something because of family."

Yet, their ahead-of-their-time arrangement proved challenging at times. Beatrice recounts the "abuse" that Paul took from nurses in pediatrician's offices who refused to speak to him, and work associates who joked about the baby who came with him everywhere. Paul laughed them off and took it all in stride as he accompanied his two children to after-school activities, went to parent-teacher meetings, and recorded kids' concerts when Beatrice was away. She says:

He gave up his whole manhood to support me. He gave up what most men would never have given up. He had it much harder than I did. It's much more difficult to be a supportive husband at home. And [Paul] did take second place. But if it bothered him, he certainly never showed it.

\section{Nancy Burns: The "Tag-along" Wife}

Nancy Burns is the 67-year-old executive vice president of a large consulting firm, an executive coach, public speaker, and published author. She describes herself as her husband Jack's “tag-along" wife because for many years she followed his work moves, and her career could not really take hold until Jack retired. To keep her mind busy, she held various jobs, including substitute teaching, running a restaurant, managing an art gallery, and volunteering. She says: "What I am doing now is almost a sum total of what l've done throughout."

Nancy mentions character traits such as responsibility and service to others as foundational to her advancement. She also points out that her parents instilled in her the belief that she could achieve anything. In turn, Nancy relayed the same message to her now adult children, who look up to her and who have gone on to excel in their own fields. 
Her husband Jack's support of her career has been ambivalent but has evolved over time. His successful career and good income meant that Nancy's aspirations were "always secondary" and that she had to "start over" with each move. She says that Jack was supportive of her working outside the home to the extent that she remained focused on the family, a role she greatly enjoyed. For much of their marriage, he filled the traditional breadwinner role and rarely helped with home matters.

Once he retired and they settled in one place, Nancy's career soared, and Jack had to make the mental transition from Nancy's work being something she "enjoyed on the side" to a bona fide career. For a while, he found that change puzzling and threatening, because "if asked, he would still believe that a woman's place is in the home and a man's place is out there with the business." Nancy jokes that he would have preferred her going to knitting club, but understood that this would simply not have satisfied her. She is happy that Jack has been "evolving," in that he has begun to display greater respect for her achievements and has taken over some of the household chores.

Nancy is well aware of the generational nature of his behavior. She recalls how Jack never had pictures of his family in his office and felt it inappropriate to discuss personal matters at work. He seldom accompanied her to doctors' appointments when she was pregnant, while their son-in-law frequently accompanied their daughter. Nancy believes couples from her children's generation have much "healthier" relationships and better balance between home and work. She feels strongly that such balance makes women "whole" human beings and in turn better parents.

\section{Jada Christopher: Having It All Later in Life}

Fifty-six-year-old Jada Christopher is the president of a regional college. She explains that the most stressful aspect of her job is reconciling the interests of the stakeholders she answers to, including faculty, staff, students, the community, and the board. She exudes a sense of assuredness. One can tell she has known for a long time that she was made for this job. She gave herself a ten-year window and prepared for executive work through education and training within national leadership organizations. Well aware of the glass ceiling, she confidently says that she does not feel her gender was a real barrier, but rather one of the reasons she believes she is effective. She deems women as better able to shift between transactional and transformational modes of leadership and as having an inherent ability to deal with the "human dimension." She was never afraid to start at the bottom and work her way up, and credits past supervisors for giving her opportunities to prove herself.
When it came to her marriage, however, the issues proved more intractable. In public, husband Ian showed nothing short of pride in her accomplishments. He would boast to friends and family members and throw lavish parties to celebrate milestones. He even relocated with her later in their marriage. But their private interactions were different. When Ian traveled on business, he assumed that Jada would take care of the household responsibilities, but when she traveled, he would complain about the household and childcare duties she was leaving behind. He routinely accused her of infidelity and rarely acknowledged how demanding her work was or her sheer passion for it, though he valued the money she brought home. As she rose in prominence and her life filled up with social functions, Ian refused to accompany her. Jada recognizes that their personality differences and the gap in their socio-economic backgrounds contributed to their problems.

To compensate for lack of support at home, Jada developed an external social network of friends, colleagues, a counselor, and mentors within professional associations. She eventually ended her marriage and is now in a relationship with a man whom she says is able to balance her public self with his interest in her as a woman. She is now fulfilled at home and in her career, but at times wonders whether she would have succeeded as well professionally if her marriage had been more gratifying.

\section{Michelle D'Angelo: Hesitant Motherhood}

To look at 38-year-old Michelle D'Angelo's life, one can easily say she has it all. She is married to her beloved Derek and has the job she has always dreamed of as vice president for a well-known record label, rubbing shoulders with the cream of America's music industry. Her job involves frequent travel, long hours, dinner meetings, and late night entertaining.

She partly credits her rise to senior management to her Ivy League education, which she says put her "in a certain category" and exposed her to networking opportunities that helped her land her first job in the industry. She also relied on that network to develop mentors, cultivate collegial relations, and create reliable sources of advice and support. She acknowledges the head of her company, who gave her numerous advancement opportunities, and her parents as contributors to her success.

The support of husband Derek has been more ambiguous, however. Michelle describes him as a "stand-up person." She praises his honesty and integrity, and credits their similar backgrounds for cultivating familiarity between them. Michelle says she just could not do without his professional expertise. He is her "go-to person" when she is having problems of a political nature at work or is negotiating a deal. She 
says they also share household chores equitably at her "insistence."

On the other hand, his work as a senior executive in the conservative manufacturing sector makes him less understanding, and occasionally jealous, of her late night schedule. He finds it difficult to comprehend that when Michelle returns late with alcohol on her breath, she had been indeed "working." To an extent, she understands him and explains that she would probably feel as "threatened" if his job made him socialize with the glitterati. But she cannot help but feel "betrayed" because, although Derek knows of her passion for her work, he would be quite pleased if she decided to quit and stay home full-time to raise the children they both desire. Indeed, Michelle's need for career/family balance fueled her move from a wellpaying job in finance to her present career in entertainment:

When I first came out of [Ivy League] I worked at [Wall Street Firm]. I enjoyed my job. I enjoyed the pace. I loved the money. But while there, I did notice the women who were managing directors, and several were unmarried with no kids and in their midthirties and early forties, and just miserable. Others were married with kids but never saw them because they were trying to keep up with the guys.

However, she remains fearful of parenthood because it might solidify the now-loose gender norms inside her marriage and entrench Derek further in his work:

He can work even harder if he wants; it's socially acceptable because now he's got more mouths to feed. So if he starts coming home later than me, that's okay because he makes much more money than I do. And he's got kids to provide for so he can say, "I've got kids to feed."

She suspects that his attitude towards her role in the family will change as well. While she knows that he would be of some help, she also realizes that he was raised by a mother who stayed home full-time and worries that he may not support her work commitment in the same way.

\section{WHAT CAN AMBITIOUS WOMEN LEARN FROM THESE STORIES?}

The dual devotion to a leadership career and a family is a tough endeavor. On the work front, several women mentioned encountering challenges rising up the ladder, including working long hours, traveling fre- quently, and experiencing the emotional tug-of-war between executive and family responsibilities. Other challenges were gender-related, including experiencing inhospitable workplaces and delayed promotions. On the home front, even the more supportive marriages involved compromise around whose career takes precedence and who handles domestic work. Still, these executive women were fulfilled at home and at work, and young, ambitious women have much to learn from them.

\section{Character Matters}

It seems that the very act of dealing with career and family challenges requires a certain character and outlook on life. Nancy spoke of personal responsibility and a service orientation, Helen of tenacity and selfconfidence, Liz of measured risk-taking, and Beatrice of optimism when she said, "I knew it would all work out in the end." A diligent work ethic ("hustling") is also necessary because enjoying career and family is often difficult.

Combining executive work with family also requires consideration of one's options, astute organization, and conscientious self-management. Some have referred to this as a "protean career attitude" or an individual's proactive and self-directed management of life and career, consistent with values and in the spirit of personal responsibility (see the 2008 article of De Vos \& Soens in Journal of Vocational Behavior).

Finally, women need to engage in introspection and self-examination. As stated by Liz: "Think about that stuff early. It might change what you do in your education and your career, and even who you pick as a husband." Many of our subjects rejected the notion that they needed to choose between career and family. Instead, they embraced the belief that they were entitled to "have it all." Taken together, these attitudes and beliefs combine to create what some have termed "psychological capital," meaning an individual's optimistic appraisal of circumstances driven by competence, confidence, and perseverance.

\section{It Matters Where You Work}

Another idea emerging from these cases is that achieving fulfillment as an executive woman while enjoying a family life requires careful consideration of the nature of the employing industry and organization. Some of our women had a clear vision of the path ahead of them while others reached their leadership aspirations rather serendipitously. Mary, Jada, and Beatrice all knew they wanted to become leaders and followed a linear path to the top. Conversely, Helen and Nancy both assumed a variety of jobs in a variety of industries until finding the work that 
allowed them to grow in ways congruent with their values. In Nancy's case, her initial options were constrained by her husband's moves and the norms within her marriage. Other women reevaluated their choices and made amendments.

Regardless of whether their current positions were reached by choice or by chance, our subjects were presently in organizations where they had attained senior ranks, had access to supportive work relationships, and enjoyed collegial esteem. Ambitious women must remember that despite the wide availability of family policies, organizations vary in their assumptions about commitment and performance and the extent to which they acknowledge the pull of family on people. These cultural tendencies are manifested in the distribution of opportunities, the provision of support networks, and the existence of mentoring relations, all of which influence women's advancement and their ability to combine career and family. Women must be conscious of their choices, but this does not necessarily mean that they must shy away from maledominated environments. For example, Beatrice Bilyk was "allowed to fly" in a very masculine workplace. However, she admits she would not have been able to succeed had it not been for Paul assuming full-time care for the home and their children. Thus, women must carefully examine their support systems vis-àvis the cultures and work practices of their chosen fields.

\section{It Takes a Village}

Another emerging theme is that it takes a village for ambitious women to combine career and family. The women we studied managed to reach leadership positions while enjoying family in part because they created complex support systems across domains of work, family, and community. In her book Basic Black: The Essential Guide for Getting Ahead at Work (and in Life), Hearst Magazines president Cathie Black states that women will find the balancing act much easier if they allow themselves to involve their families and communities in their personal lives. The case of Jada Christopher also indicates that women can compensate for the lack of support in one area by developing support networks elsewhere. Engaging in social exchange and mutually nurturing relationships is a powerful way that women cope with the stress of multiple role demands. These interactions provide support, insight, and resources, and are critical to women's career success and overall wellbeing.

\section{It Matters Whom You Marry}

Partners are critical to ambitious women's quest for career/family balance. Our subjects' experiences illustrate a wide range of supportive stances from partners, ranging from Jada's difficult marriage to Beatrice's husband who she says "sublimated himself" for her. When husbands are supportive, their support can be both emotional (providing advice, encouragement, and emotional regulation) and instrumental (technical support and professional assistance). In some cases, men even take on stereotypically feminine behaviors like staying home with the children or relocating with their spouse. Many of our subjects indicated that ambitious women should carefully choose their life partner. One emphatically described that choice as "probably the most important decision" to make in trying to combine work and family.

The partner's career and background seem to matter greatly. Our cases as well as other examples in the press indicate that the partner's line of work can make a big difference in an executive woman's effort to balance career and family. Peggy Walsh, senior vice president at a global public relations firm, believes that her husband's work as a teacher whose schedule mirrors that of their three young children has been a "lifesaver" for her family. The husband of Liz Connelly, J.P. Morgan Chase \& Co. executive and mother of four, earns his money managing rental properties. His flexible schedule allows him to handle all after-school activities.

Subjects Michelle, Helen, and Beatrice also credited similar cultural backgrounds as helping their relationships, in particular their partner's upbringing. Beatrice mentions that her mother-in-law was the reason why Paul was so "respectful" of her and of women in general. Conversely, Michelle mentions that husband Derek was raised by a stay-at-home mother, a "powerful model" for a man and one likely to influence Derek's own expectations. There were also references to the husband's character, where he is often described as enlightened and unintimidated by the woman's success.

\section{Life Strategies}

Last, we find that the women designed career and family strategies that unfolded over time, reflected the women's values, and accounted for the availability of support at home and at work - including working around the partner's support, outsourcing domestic work, and sequencing career and family.

Most of our subjects found the need to work around their partner's support. Liz praises her partner's aid with her business and his esteem support, but she still wishes he helped more around the house and deliberately organizes her schedule around his. Nancy and Mary felt their advancement was subject to their husbands' moves. It seems necessary to navigate the partner's support, but worth remembering that even the most traditional of men can evolve, as illustrated by Jack Burns, who has come to accept the success 
enjoyed by his wife, Nancy. Even there, Nancy acknowledges that his breadwinning role gave her a platform of freedom to experiment with various occupations. Jada and Helen's stories also indicate that women cannot always successfully navigate the spousal support role and may end their relationships in search of partners who are supportive of both their career and family aspirations.

The women's busy lives and desire for balance also led them to question the "superwoman" notion that women need to do it all. Sara Moss, general counsel of the Estée Lauder companies, states that "there are no superwomen among women at this level." Our subjects indicated that they had to be selective with the roles they played, so they devoted themselves to leadership and mothering but shared or outsourced domestic roles. The frequently espoused strategy of outsourcing home chores was made possible by the women's income. At times, outsourcing was a way for our subjects to steer through the partner's lack of domestic support and avoid marital tension.

Another life strategy was the purposeful sequencing of career relative to family. For some, career and family took turns; for others, they were pursued in tandem while exhibiting extreme organization and outsourcing much of the work. When career and family took turns, some women chose to devote themselves to family and childrearing before they seriously pursued their leadership ambitions. Others postponed marriage, delayed childbearing, or decided not to have children to advance in their career. They recognized the potentially drastic effects of childbearing on the division of career and family roles.

In all, the strategy of living life in a chapter-like fashion suggests that work-life "balance" is not a daily state of affairs but a personal and continuously reexamined goal that unfolds over a lifetime. There may be periods in people's lives where one or a few roles assume prominence to the necessary detriment of others. Mainiero and Sullivan explored that idea in their work on "kaleidoscope" careers, suggesting that women do not "opt out" so much as they position their careers within their life context. Thus, instead of asking, "Am I in a state of balance today?" one should ask whether one's actions are conducive to balance over time, and some researchers have indeed called for a "life course" approach to work and family balance (see, for example, the works of sociologist Phyllis Moen). This in turn leads us to reflect on the expressions: "having it all" and "work-life balance."

\section{RETHINKING THE WORDS WE USE}

We believe that the role of researchers, or of anyone interested in the advancement and fulfillment of women, should shift from the pessimistic stance of career/family choices to a better understanding of how women have gone about the allegedly elusive goal of "having it all." This is a different line of research from the stream creating metaphors to describe the obstacles faced by women, whether they be "glass walls," "concrete ceilings," or "glass cliffs." Our findings also lead us to revisit the expressions that we use in describing people's attempts to lead rich and multifaceted lives. We believe that we fundamentally wrong women (and their potential employers) when we stick to vague expressions such as "having it all" and "work-life balance" as metaphors of a life well lived, and then tell women that it shall remain an elusive goal.

For one, the expression "having it all" is misleading in all of its three words. Enjoyment of social roles such as that of leader, spouse, or parent are not things that can be had or acquired. The words "it" and "all" are vague and denote "everything," when no one really can or wants to have everything or do everything. By choosing to be executives or family members, many of our subjects most likely had to sacrifice other roles. Nevertheless, they felt fulfilled in their lives even if that feeling was not felt every day or if it took a lifetime to experience. Cathie Black states "hating" the expression because it overshadows the idea of each individual pursuing "their all." Many of the women we studied echoed that sentiment, stressing that individuals should "create their own balance."

The widely used expression "work-life balance" also has its limitations, beginning with the lack of an agreed-upon definition. Many characterizations populate the literature, including the simple assuming of multiple roles and fairness between roles. Some have argued that the "balance" metaphor makes people focus on equality between sections of their existence instead of leading integrated lives. It also suggests that there is an appropriate distribution of time between pursuits, which discounts the complex and value-driven processes by which people make sense of their lives. Penny Herscher, CEO of research firm FirstRain, states that balance is a "myth" for executive women, but they can still thrive if they prioritize and are conscious of their choices.

Balance also implies a distinction between work and everything else when there are not always clearcut distinctions. For many, work is a big part of life, if not life itself. What are missionaries, entrepreneurs, and artists to make of the expression "work-life balance"? Others have questioned the word "life," which has occasionally been interchanged with "work-nonwork" or "work-family" balance, illustrative of the expression's very inelegance. Some have argued that the "life" component varies widely in people's experiences and can include cultural and religious components not usually discussed. Finally, the expression has been criticized because it can imply more play and less work, hinting that work always exhausts one's 
resources, when one's occupation can be extremely meaningful and rewarding.

We propose going back to the simple word "living" and invite women to create their own career and family metaphors. We hope that rethinking our language will also encourage researchers and society in general to revisit the assumption of an either/or choice between career and family for ambitious women. 


\section{SELECTED BIBLIOGRAPHY}

The obstacles to advancement encountered by women are discussed in the Harvard Business Review articles of Alice H. Eagly and Linda L. Carli, "Women and the Labyrinth of Leadership," 2007, 85, 62-71: and Anna Fels, "Do Women Lack Ambition?" 2004, 82, 50-60. Our discussion of the factors underlying women's advancement was informed by the works of Lisa A. Mainiero, in particular her 1994 articles, "Getting Anointed for Advancement: The Case of Executive Women," in Academy of Management Executive, 8, 53-67; and "On Breaking the Glass Ceiling: The Political Seasoning of Powerful Women Executives," in Organizational Dynamics, 22, 5-20.

The work-life challenges encountered by executive women have been extensively studied by Mary BlairLoy in her 2001 Gender E Society article "Cultural Constructions of Family Schemas: The Case of Women Finance Executives," 15, 687-709; Sylvia Ann Hewlett in her 2002 Harvard Business Review article "Executive Women and the Myth of Having It All," 80, 66-73; and Karen S. Lyness and Michael K. Judiesch in their 2008 article "Can a Manager Have a Life and a Career?: International and Multisource Perspectives on Work-
Life Balance and Career Advancement Potential," in Journal of Applied Psychology, 93, 789-805.

Our discussion of coping with career and family pressures was informed by the works of James C. Quick and Jonathan D. Quick, including "The Balancing Act: At Work and at Home," in Organizational Dynamics, 2004, 33, 426-438 (with Amy B. Henley) and "A Spirit of Personal Integrity: The Role of Character in Executive Health," in Organizational Dynamics, 2003, 32, 165-179 (with Joanne H. Gavin and Cary L. Cooper).

For insightful reflections on the concept of "balance," see the works of Paula J. Caproni ("Work/Life Balance: You Can't Get There From Here," in Journal of Applied Behavioral Science, 1997, 33, 46-56), Edy Greenblatt ("Work/Life Balance: Wisdom or Whining," in Organizational Dynamics, 2002, 31, 177-193), Stephen K. Hacker and Toni L. Doolen ("Strategies for Living: Moving From the Balance Paradigm," in Career Development International, 2003, 8, 283-290), and Jeffrey A. Thompson and J. Stuart Bunderson ("WorkNonwork Conflict and the Phenomenology of Time: Beyond the Balance Metaphor," in Work and Occupations, 2001, 28, 17-39).

Souha R. Ezzedeen, Ph.D., joined York University in 2007 as assistant professor of human resource management. Previously, she was assistant professor of management at the Pennsylvania State University at Harrisburg's School of Business Administration. She holds a doctorate in human resource management and organizational behavior and development from the George Washington University School of Business in Washington, DC, where she served as a research fellow and visiting instructor. She has authored several journal articles on topics including strategic human resource management, work-life conflict and balance, and social support. Her work has appeared in journals such as Psychological Reports, Human Resource Planning, and Journal of Family Issues. Discussions of her findings have appeared in the Wall Street Journal (online) and SHRM research reports, among others. She is a two-time winner of the Michael J. Driver Best Careers Paper in the Regions Award presented at the annual meeting of the Eastern Academy of Management (School of Human Resource Management, York University, 4700 Keele Street, Toronto, ON, Canada M3J 1P3. Tel.: +1 416736 2100x20269; fax: +1 416736 5963; e-mail: souha@yorku.ca).

Kristen G. Ritchey, M.B.A., holds a degree in American studies from Georgetown University, Washington, D.C., and a master of business administration from the Pennsylvania State University at Harrisburg. She is currently government and community affairs manager at Comcast Corporation. Her work on the spousal support received and valued by executive women was published in the Journal of Family Issues, 
and was cited in the Wall Street Journal (online) and daily papers including the Vancouver Sun in Canada and the Herald Sun in Australia (Government and Community Affairs, Comcast Corporation, Harrisburg, PA, USA. Tel.: +1 717545 0216; fax: +1 717651 1961; e-mail: kristenritchey@comcast.net). 